\title{
China's Outward Foreign Direct Investment Patterns: Evidence from Asian Financial Markets
}

\author{
Yugang $\mathrm{HE}^{*}$, Baek-Ryul CHOI** \\ Received: October 03, 2019 Revised: October 13, 2019 Accepted: November 30, 2019
}

\begin{abstract}
Since the economic crisis sweeps across the world in 2008, the foreign direct investment of various countries has been greatly impacted. Therefore, this paper regards China as an example to analyze China's outward foreign direct investment patterns in terms of Asian financial markets with a panel data over the period 2003-2017. We mainly focus on the money market oriented outward foreign direct investment and foreign exchange market oriented outward foreign direct investment. Using the individual fixed effect model to conduct empirical analyses, the empirical findings indicate that China will reduce its foreign direct investment amount to a country with large money supply and China will increase its foreign direct investment amount to a country with large foreign exchange reserves. Furthermore, when a country has signed Free Trade Agreement with China, China will increase more foreign direct investment amount to these countries than that of a country who has not signed Free Trade Agreement with China. Moreover, the empirical findings indicate that no matter what the money market oriented outward foreign direct investment or foreign market oriented outward foreign direct investment, China will reduce its foreign direct investment amount to these Asian countries due to the global economic crisis.
\end{abstract}

Keywords: Outward Foreign Direct Investment Patterns, Asian Financial Markets, Global Economic Crisis, Individual Fixed Effect Model, Free Trade Agreement

JEL Classification Code: C33, C36, F00, G00.

\section{Introduction}

As the largest developing country, China is the second largest economic entity in the world. In recent years, with the rapid improvement of science and technology, China's domestic output has increased substantially. Domestic demand has been greatly met, and there has been a large amount of excess capital. For the rational use of excess capital, the Chinese government has issued a number of policies, such as the Building-up of Asian Infrastructure Investment Bank and the implementation of "One Belt and One Road" to transfer excess domestic capital to foreign countries. Meanwhile, the deepening of Reform and Opening-up Policy also creates favorable policy support for

\footnotetext{
* First Author, Doctoral Student, Department of International Trade, Jeonbuk National University, Korea.

Email: 1293647581@jbnu.ac.kr

* * Corresponding Author, Professor, Department of International Trade, Jeonbuk National University, Korea.

Email: brchoi@jbnu.ac.kr

๑ Copyright: Korean Distribution Science Association (KODISA)

This is an Open Access article distributed under the terms of the Creative Commons Attribution NonCommercial License (https://creativecommons.org/licenses/by-nc/4.0/) which permits unrestricted noncommercial use, distribution, and reproduction in any medium, provided the original work is properly cited.
}

Chinese enterprises to invest overseas. On September 28, 2018, the National Bureau of Statistics and State Administration of Foreign Exchange of China and the Ministry of Commerce have jointly issued the "2017 Statistical Bulletin of China's Outward Foreign Direct Investment". As this report indicates, China's outward foreign direct investment in 2017 amounts to \$158.29 billion. Compared with that in 2016, China has experienced negative growth which does not happen before since the annual statistics are released in 2003, but it is still the second highest in history. Moreover, it accounts for more than $10 \%$ of the global share for two consecutive years. Because the influence of China's outward foreign direct investment is expanding, the scale of China's outward foreign direct investment has been the third largest in the world and lags behind that of the United States and Japan.

In recent years, with the increase of global uncertainties, the patterns and scales of outward foreign direct investment in each country will be greatly affected. Therefore, this paper uses China as an example to exploit China's outward foreign direct investment patterns in terms of Asian financial markets with a panel data over the period from 2003 to 2017. According to the general international 
standards, financial markets can be divided into capital market, money market, gold market and foreign exchange market. This paper mainly concentrates on the impact of external factor from target countries' money market and foreign exchange market on China's outward foreign direct investment patterns. Stated differently, we will mainly take the money market oriented outward foreign direct investment and the foreign exchange market oriented outward foreign direct investment. Moreover, with the deepening of economic globalization, China have signed the Free Trade Agreement with many Asian countries to serve for international economic cooperation.

This kind of economic behavior may affect China's outward foreign direct investment patterns to Asian countries. Due to this reason, two dummy variables are set to solve the problem from the Free Trade Agreement. Furthermore, the global economic crisis happened in 2008 as a representative of global economic uncertainty is taken into consideration. We set a dummy variable about the global economic crisis to examine the changes of China's outward foreign direct investment patterns to Asian countries before and after the global economic crisis. Using the individual fixed effect model to conduct empirical analyses, we have come to four findings: First, when a country has a large amount of money supply, China will reduce its foreign direct investment amount to that country. Second, when a country has a large number of foreign exchange reserves, China will increase its foreign direct investment amount to that country. Third, when a country has signed the Free Trade Agreement with China, this country will receive more China's foreign direct investment amount than that of a country has not signed the Free Trade Agreement with China. Finally, no matter what the money market oriented outward foreign direct investment or the foreign market oriented outward foreign direct investment, China will reduce its foreign direct investment amount to these target Asian countries due to the global economic crisis.

To this end, the rest of this study will be formed as follows: Chapter two will analyze the literature review. Chapter three will present the theoretical framework. Chapter four will present the results. Chapter five will present the conclusion.

\section{Literature Review}

Actually, there are many literature involving China's foreign direct investment. The main purpose of this chapter is to collate and summarize the previous relevant literature. Then, by comparing these documents, we will show the innovation of this paper. In general, the determinants of foreign direct investment can be divided into two categories. One is the internal determinants such as domestic economic growth and domestic employment. Another is the external determinants such as investment target country's interest rate and inflation.

As for the internal determinants, Lee (2010) takes use of Japan's data to analyze the effect of economic growth on outward foreign direct investment within the Granger causality framework. His finding demonstrates that there is a long-run positive one-way causal relationship between outward foreign direct investment and GDP per capita. However, this kind of relationship does not exist in the short run. Chen and Zulkifli (2012) set Malaysia over the period from 1980 to 2010 as a sample to explore the association between OFDI and economic growth using the multivariate framework. Using the vector error correction model, their findings indicate that a long-run positive relationship between economic growth and OFDI exists. Meanwhile, the result of causality shows that there is a two-way causality between both of them in the long run. But, in the short run, they do not find the Granger causality between economic growth and outward foreign direct investment. Wang, Cheng, Wang, and Li (2014) employ the dynamic threshold model to discuss the effect of economic growth (it is replaced by the institutional quality) on outward foreign direct investment with a sample of 73 countries over the period of 2000 to 20008 . They find that the economic growth has a strong effect on outward foreign direct investment only when the institutional quality is within a certain range. However, the low institutional quality which is accompanied by the low economic development will not promote the outward foreign direct investment significantly.

Wei, Alon, and Ni (2012) attempt to explore the home country's macroeconomic determinants on China's outward foreign direct investment. They find that the foreign exchange reserves have a positive effect on China's OFDI. In terms of foreign exchange market, He (2018) set china as an example to exploit the effect of macroeconomic variables on China's OFDI to Japan. Using vector error correction model to conduct empirical analyses, he finds that the real exchange rate is positively associated with China's OFDI to Japan. However, the real exchange rate volatility, trade openness and real GDP are negatively related to China's OFDI to Japan. In terms of money market. Patel and Mah (2018) employ the time series data over period from 1980 to 2015 with a sample of South Africa. Based on estimation of vector error correction model, they also find that the money supply is negatively related to the OFDI.

As for the external determinants, Chou, Chen, and Mai (2011) use the spatial econometric model to investigate the influence of economic integration on China's outward foreign direct investment. They find that the political risks 
of host countries have a negative impact on China's OFDI. The similarity with Chinese Culture and GDP per capita of host countries are positively related with China's outward foreign direct investment. Moreover, the market opportunities of the host countries have a significant negative impact on China's outward foreign direct investment. Blomkvist and Drogendijk (2013) attempt to analyze the impact of psychic distance and its individual stimuli (differences in geographic distance, language, economic development, religion, culture and political systems, education) on China's outward foreign direct investment. Using the ordinary least squares to conduct empirical analyses, they find that its stimuli and the psychic distance can not be left out as explanatory factors for Chinese outward foreign direct investment.

Lee and Zhai (2013) and Kang and Kim (2014) use different samples to analyze this proposition and obtain the same conclusions. Bhasin and Jain (2015) explore the role of host country factors in attracting India's outward foreign direct investment by using panel data of 15 host countries over the period from 2000 to 2009. they find that the technology, bilateral investment treaties and the opening up of host countries are important determinants of India's outward foreign direct investment. Li, Huang and Dong (2019) adopt the panel smooth transition regression model to study the nonlinear effects of outward foreign direct investment in 12 "One Belt and One Road" countries over the period from 2010 to 2015 . They find that both overall economic freedom, the interaction of economic freedom and patent, bilateral trade, GDP and institutional instance significantly influence the outward foreign direct investment. Moreover, they also find that economic freedom and economic development have the inverted " $U$ " effect on outward foreign direct investment in the different regime.

The above literature analyses the impact of internal and external factors on outward foreign direct investment. Compared with these literature, this paper sets China as an example to analyze China's outward foreign direct investment patterns in terms of Asian financial markets (money market and foreign exchange market) with a panel data over the period from 2003 to 2017. It is also the innovation of this paper to find out the influencing factors of outward foreign direct investment from the financial markets.

\section{Theoretical Framework}

\subsection{Model Specification}

Generally speaking, there are two main factors affecting the outward foreign direct investment (OFDI) patterns. One is the internal factor (factors of home country affecting the outward foreign direct investment to target country). Yan, Zhang, Shen and Han (2018) attempt to explore the link between productivity, financial constraints and outward foreign direct investment with firm-level evidence. As internal factors, they find that both financial constraints and productivity are important factors which can affect firm's ability to perform the outward foreign direct investment. Wei, Zheng, Liu and Lu (2014) also perform a research about internal factors that expand to the outward foreign direct investment. They find that national and sub-national institutions, export experience, productivity, capability and entry barriers affect the outward foreign direct investment decisions. The other is the external factor (factors of target countries affecting the outward foreign direct investment patterns of home country). Liu, Ge, Hu and Wang (2018) try to explore the spatial differentiation of China's OFDI. As external factors, they find that the U-shaped curve relationship between cultural distance and China's outward foreign direct investment exists. Furthermore, their findings indicate that China's OFDI does not merely flow to similar cultural economy. Clegg, Lin, Voss, Yen and Shih (2016) employ panel data of 4619 observations from 261 Chinese publicly listed firms from 1991 to 2011 to analyze factors that may affect the outward foreign direct investment patterns. They find that the host-country risk is an important factor for a home country to conduct the outward foreign direct investment to the host-country. Yoo (2016) analyze this proposition in terms of ASEAN countries. He finds that ASEAN FTA is not effective to attract FDI.

Compared with others, in this paper, we try to explore the external factor from target countries' financial markets. According to the general international standards, financial markets can be divided into gold market, capital market, money market and foreign exchange market and. This paper mainly concentrates on the impact of external factor from target countries' money market and foreign exchange market on China's outward foreign direct investment patterns. Due to that there are a lot of indexes to measure the target countries' money market and foreign exchange market, in this paper, the money market oriented outward foreign direct investment is represented by the money supply of each target country. Foreign exchange market oriented outward foreign direct investment is represented by the foreign exchange reserve of each target country. Moreover, as the market size and productivity of target countries are two important factors affecting China's OFDI patterns, both of them are taken into account in this paper. The basic estimated equation gives:

$$
\begin{aligned}
& \log \text { ofdi }_{i, j, t}=a_{0}+a_{1} \log \text { money }_{j, t}+a_{2} \log \text { exchange }_{j, t} \\
& +a_{3} \log g d p_{j, t}+a_{4} \log \text { gdppc }_{j, t}+\eta_{i}+\delta_{t}+\mu_{i, t}
\end{aligned}
$$


Where $i$ represents China. $t$ represents the year. $j$ represents the target country. ofdi represents China's foreign direct investment amount to each target country. money represents the money supply of each target country. exchange represents the foreign exchange reserve of each target country. $g d p$ represents the GDP of each target country. gdppc represents the GDP per capita of each target country. $\eta_{i}$ represents the individual effect. $\delta_{t}$ represents the time effect. $\mu_{i, t}$ represents the white noise. $\log$ represents logarithmic value of each variable.

Since the impact of Free Trade Agreement (FTA) on China's outward foreign direct investment patterns can not be ignored, this paper estimates China's outward foreign direct investment patterns between countries who have signed FTA with China and those who have not signed FTA with China, respectively. Using dummy variables and mutual variable to conduct empirical analysis, we can compare elastic coefficients of different countries. The estimated equation about the money market oriented outward foreign direct investment give:

$$
\begin{aligned}
& \log \text { ofdi }_{i, j, t}=\beta_{0}+\beta_{1} \log \text { money }_{j, t}+\beta_{2} \log \text { exchange }_{j, t} \\
& +\beta_{3} \log g d p_{j, t}+\beta_{4} \log g d p p c_{j, t} \\
& +\beta_{5} f t a_{m} \bullet \log \text { money }_{j, t}+\beta_{6} f t a_{m} \bullet \log g d p_{j, t} \\
& +\beta_{7} f t a_{m} \bullet \log \text { gdppc }_{j, t}+\eta_{i}+\delta_{t}+\mu_{i, t}
\end{aligned}
$$

Where $f t a_{m}$ represents the countries that have signed FTA with China (money market oriented outward foreign direct investment). If a country has signed FTA with China, the value will be one. Otherwise, zero. $\beta_{1}$ represents the coefficient of money market oriented outward foreign direct investment amount (countries that have not signed FTA with China). The sum of $\beta_{1}$ and $\beta_{5}$ represents the coefficient of money market oriented outward foreign direct investment amount (countries that have signed FTA with China). $\beta_{0}$ represents the constant. $\beta_{2}, \beta_{3}, \beta_{4}$, $\beta_{6}$ and $\beta_{7}$ are coefficients of variables, respectively. Then, the estimated equation about the foreign exchange market oriented outward foreign direct investment give:

$$
\begin{aligned}
& \log \text { ofdi }_{i, j, t}=\gamma_{0}+\gamma_{1} \log \text { money }_{j, t} \\
& +\gamma_{2} \log \text { exchange }_{j, t}+\gamma_{3} \log g d p_{j, t}+\gamma_{4} \log g d p p c_{j, t} \\
& +\gamma_{5} f t a_{e} \bullet \log \text { exchange }_{j, t}+\gamma_{6} f t a_{e} \bullet \log g d p_{j, t} \\
& +\gamma_{7} f t a_{e} \bullet \log \operatorname{gdppc}_{j, t}+\eta_{i}+\delta_{t}+\mu_{i, t}
\end{aligned}
$$

Where $f t a_{e}$ represents the countries that have signed FTA with China (foreign exchange market oriented outward foreign direct investment). If a country has signed FTA with China, the value will be one. Otherwise, zero. $\gamma_{2}$ represents the coefficient of foreign exchange market oriented outward foreign direct investment amount (countries that have not signed FTA with China). The sum of $\gamma_{2}$ and $\gamma_{5}$ represents the coefficient of foreign exchange market oriented outward foreign direct investment amount (countries that have signed FTA with China). $\gamma_{0}$ represents the constant. $\gamma_{1}, \gamma_{3}, \gamma_{4}, \gamma_{6}$ and $\gamma_{7}$ are coefficients of variables, respectively.

Furthermore, due to that the global economic crisis happened in 2008 may have a great impact on China's OFDI patterns, we will set a dummy variable about the global economic crisis $\left(d_{2008}\right)$. If the year before 2008 , the value of $d_{2008}$ will be zero. And if the year after 2008, the value of $d_{2008}$ will be one. The estimated equation (in terms of money market oriented outward foreign direct investment) about the global economic crisis gives:

$$
\begin{aligned}
& \log \text { ofdi }_{i, j, t}=\lambda_{0}+\lambda_{1} \log \text { money }_{j, t}+\lambda_{2} \log \text { exhange }_{j, t} \\
& +\lambda_{3} \log g d p_{j, t}+\lambda_{4} \log g d p p c_{j, t} \\
& +\lambda_{5} d_{2008} \bullet \log \text { money }_{j, t}+\lambda_{6} d_{2008} \bullet \log g d p_{j, t} \\
& +\lambda_{7} d_{2008} \bullet \log g d p p c_{j, t}+\eta_{i}+\delta_{t}+\mu_{i, t}
\end{aligned}
$$

Where $\lambda_{0}$ represents the constant. $\lambda_{1}$ represents the coefficient of money market oriented outward foreign direct investment before 2008. The sum of $\lambda_{1}$ and $\lambda_{5}$ represents the coefficient of money market oriented outward foreign direct investment after 2008. $\lambda_{2} \lambda_{3}, \lambda_{4}$, $\lambda_{6}$ and $\lambda_{7}$ are coefficients of variables, respectively. Then, the estimated equation (in terms of foreign exchange market oriented outward foreign direct investment) about the global economic crisis gives:

$$
\begin{aligned}
& \log \text { ofdi }_{i, j, t}=\rho_{0}+\rho_{1} \log \text { money }_{j, t}+\rho_{2} \log \text { exhange }_{j, t} \\
& +\rho_{3} \log g d p_{j, t}+\rho_{4} \log g d p p c_{j, t} \\
& +\rho_{5} d_{2008} \bullet \log \text { exchange }_{j, t}+\rho_{6} d_{2008} \bullet \log g d p_{j, t} \\
& +\rho_{7} d_{2008} \bullet \log \operatorname{gdppc}_{j, t}+\eta_{i}+\delta_{t}+\mu_{i, t}
\end{aligned}
$$


Where $\rho_{0}$ represents the constant. $\rho_{2}$ represents the coefficient of foreign exchange market oriented outward foreign direct investment before 2008. the sum of $\rho_{2}$ and $\rho_{5}$ represents the coefficient of foreign exchange market oriented outward foreign direct investment after 2008. $\rho_{1}$ $\rho_{3}, \rho_{4}, \rho_{6}$ and $\rho_{7}$ are coefficients of variables, respectively. From equation (1) to equation (5), all these equations will be employed to conduct empirical analyses one by one.

\subsection{Variable Description}

Table 1: Variable Description

\begin{tabular}{|c|c|c|c|}
\hline Variable Type & Abbreviation & Definition & Source \\
\hline $\begin{array}{l}\text { Dependent } \\
\text { Variable }\end{array}$ & ofdi & $\begin{array}{l}\text { Flow of outward foreign direct investment (OFDI) amount } \\
\text { from China to each Asian country }\end{array}$ & $\begin{array}{l}2017 \text { Statistical Bulletin of China's } \\
\text { Outward Foreign Direct Investment }\end{array}$ \\
\hline \multirow{4}{*}{$\begin{array}{l}\text { Independent } \\
\text { Variable }\end{array}$} & money & Money supply of each Asian country & $\begin{array}{l}\text { International Monetary Fund } \\
\text { (International Finance Statistics) }\end{array}$ \\
\hline & exchange & Foreign exchange reserve of each Asian country & $\begin{array}{l}\text { International Monetary Fund } \\
\text { (International Finance Statistics) }\end{array}$ \\
\hline & $g d p$ & GDP of each Asian country & World Bank Open Data \\
\hline & $g d p p c$ & GDP per capita of each Asian country & World Bank Open Data \\
\hline \multirow{3}{*}{ Dummy Variable } & $d_{2008}$ & $\begin{array}{l}\text { Global economic crisis (before } 2008, d_{2008}=0 \text {; After } \\
\left.\qquad 2008, d_{2008}=1 .\right)\end{array}$ & \\
\hline & $f t a_{m}$ & $\begin{array}{l}\text { Money market oriented outward foreign direct investment } \\
\text { (Those countries that have signed FTA with China, the value } \\
\text { will be one. Otherwise, zero.) }\end{array}$ & $\begin{array}{l}\text { China Free Trade Area Service Network } \\
\text { (http://fta.mofcom.gov.cn) }\end{array}$ \\
\hline & $f t a_{e}$ & $\begin{array}{c}\text { Foreign exchange market } \\
\text { Oriented outward foreign direct investment (Those } \\
\text { countries that have signed FTA with China, the value will be } \\
\text { one. Otherwise, zero.) }\end{array}$ & $\begin{array}{c}\text { China Free Trade Area Service Network } \\
\text { (http://fta.mofcom.gov.cn) }\end{array}$ \\
\hline
\end{tabular}

\section{Results}

\subsection{Data Description and Target Countries}

This paper includes one dependent variable (OFDI), four independent variables (money supply, foreign exchange reserve, GDP and GDP per capita) and three dummy
The flow of OFDI amount from China to each Asian country is treated as a dependent variable. It is sourced from "2017 Statistical Bulletin of China's Outward Foreign Direct Investment" over period 2003 to 2017. The money supply and foreign exchange reserve are treated as core independent variables. They are collected from International Monetary Fund (International Finance Statistics) over period of 2003 to 2017. The GDP and GDP per capita are treated as control independent variables. They are obtained from World Bank Open Data over period 2003 to 2017. These countries that have signed Free Trade Agreement with China are gained from China Free Trade Area Service Network. Those variables used in this paper will be exhibited in $<$ Table $1>$.

Table 2: Data Description

\begin{tabular}{|c|c|c|c|c|c|}
\hline Variable & \multirow{2}{*}{$\log$ Statistic } & $\log$ money & $\log$ exchange & $\log g d p$ & $\log g d p p c$ \\
\cline { 1 - 5 } Mean & 2.569 & 3.305 & 1.387 & 3.750 & 2.047 \\
\hline Median & 2.697 & 3.181 & 1.420 & 3.751 & 2.193 \\
\hline Maximum & 5.019 & 6.891 & 3.113 & 4.800 & 3.793 \\
\hline Minimum & -1.000 & -1.181 & -1.069 & 2.688 & 0.033 \\
\hline Std. Dve & 1.107 & 1.625 & 0.908 & 0.679 & 0.790 \\
\hline Observation & 331 & 331 & 331 & 331 & 331 \\
\hline
\end{tabular}


Table 3: Target Countries

\begin{tabular}{|c|c|c|c|}
\hline Number & Abb & Number & Abb \\
\hline 1 & BRN & 15 & KAZ \\
\hline 2 & PHL & 16 & KGZ \\
\hline 3 & KOR & 17 & QAT \\
\hline 4 & KHM & 18 & LBN \\
\hline 5 & MYS & 19 & BGD \\
\hline 6 & THA & 20 & JPN \\
\hline 7 & SGP & 21 & NPL \\
\hline 8 & VNM & 22 & TJK \\
\hline 9 & ARE & 23 & LKA \\
\hline 10 & OMN & 24 & SAU \\
\hline 11 & PAK & 25 & TUR \\
\hline 12 & BHR & 26 & ISR \\
\hline 13 & JOR & 27 & IND \\
\hline 14 & TLS & & \\
\hline
\end{tabular}

Note: Abb indicates the abbreviation of each country's name

\subsection{Money Market Oriented Outward Foreign Direct Investment}

As well known, an increase in the money supply will arise a country's inflation. According to Fisher effect, an increase in the inflation will lower the real interest of a country. Therefore, when foreign countries invest to that country, their earnings will be reduced. Then, foreign countries will reduce the foreign direct investment account to that country. Namely, the money supply has a negative effect on FDI from other countries. Before conducting empirical analyses, we perform Hausaman tests to decide which effect is proper between random effect and fixed effect. Referring to the relevant statistics of Hausaman tests, we find that the individual fixed effect is more suitable. The estimated results of money market oriented outward foreign direct investment are shown in $<$ Table $4>$.

Table 4 presents the estimated results of money $\mathrm{m}$ arket oriented outward foreign direct Investment. In $\mathrm{m}$ odel (4), it can been found that the coefficients of $\log$ money and $\mathrm{fta}_{m} \bullet \log$ money get through the signifi cant test at $10 \%$ level. This indicates that an increase in money supply of a country who has not signed FT A with China will reduce China's foreign direct invest ment to that country. When the money supply increase $\mathrm{s}$ by $1 \%$, China's foreign direct investment to that cou ntry will be reduced by $0.378 \%$. Meanwhile, an increa se in the money supply of a country who has signed FTA with China will also reduce China's foreign direc $\mathrm{t}$ investment to that country. When the money supply increases by $1 \%$, China's foreign direct investment to that country will be reduced by $0.183 \%(-0.378 \%+0.19$ $5 \%=-0.183 \%)$. Therefore, we can conclude that in term $\mathrm{s}$ of money market oriented outward foreign direct Inv estment, a country who has signed FTA with China w ill receive more foreign direct Investment amount from China than that of a country who has not signed FTA with China.

Table 4: Results of Money Market Oriented Outward Foreign Direct Investment

\begin{tabular}{|c|c|c|c|c|}
\hline \multirow{3}{*}{\begin{tabular}{|c} 
Dependent Variable \\
Model \\
Independent Variable
\end{tabular}} & \multicolumn{4}{|c|}{$\log o f d i$} \\
\hline & \multirow{2}{*}{$\begin{array}{l}\text { Model } \\
\text { (1) }\end{array}$} & \multirow{2}{*}{$\begin{array}{l}\text { Model } \\
\text { (2) }\end{array}$} & \multirow{2}{*}{$\begin{array}{l}\text { Model } \\
\text { (3) }\end{array}$} & \multirow{2}{*}{$\begin{array}{l}\text { Model } \\
\text { (4) }\end{array}$} \\
\hline & & & & \\
\hline $\log g d p$ & $\begin{array}{c}1.566 * * * \\
(0.575)\end{array}$ & $\begin{array}{l}1.557 * * \\
(0.685) \\
\end{array}$ & $\begin{array}{l}1.571 * * \\
(0.780)\end{array}$ & $\begin{array}{l}1.556^{* *} \\
(0.776)\end{array}$ \\
\hline $\log g d p p c$ & $\begin{array}{l}1.567 * * \\
(0.785) \\
\end{array}$ & $\begin{array}{l}1.549^{*} \\
(0.818)\end{array}$ & $\begin{array}{l}1.497^{*} \\
(0.833)\end{array}$ & $\begin{array}{c}1.377 \\
(0.907)\end{array}$ \\
\hline $\log$ money & $\begin{array}{c}-0.351^{* *} \\
(0.128)\end{array}$ & $\begin{array}{l}-0.354 \\
(0.231)\end{array}$ & $\begin{array}{l}-0.350 \\
(0.229)\end{array}$ & $\begin{array}{l}-0.378^{*} \\
(0.232)\end{array}$ \\
\hline log exchange & $\begin{array}{c}0.704^{* *} \\
(0.326) \\
\end{array}$ & $\begin{array}{l}0.703^{*} \\
(0.367) \\
\end{array}$ & $\begin{array}{c}0.703 \\
(0.426) \\
\end{array}$ & $\begin{array}{c}0.709^{* *} \\
(0.326) \\
\end{array}$ \\
\hline$f t a_{m} \bullet \log g d p$ & & $\begin{array}{l}0.031 * * \\
(0.013)\end{array}$ & & \\
\hline$f t a_{m} \bullet \log g d p p c$ & & & $\begin{array}{l}-0.111 \\
(0.927)\end{array}$ & \\
\hline$f t a_{m} \bullet \log$ money & & & & $\begin{array}{l}0.195^{*} \\
(0.122)\end{array}$ \\
\hline constant & $\begin{array}{c}-8.647 * * * \\
(2.169) \\
\end{array}$ & $\begin{array}{c}-8.595 * * * \\
(2.255)\end{array}$ & $\begin{array}{c}-8.628 * * * \\
(2.178)\end{array}$ & $\begin{array}{c}-8.925^{* * *} \\
(2.213)\end{array}$ \\
\hline Hausaman Test & $\begin{array}{l}\chi^{2}(4)=134.682 \\
(\mathrm{P}-\mathrm{value}=0.00)\end{array}$ & $\begin{array}{l}\chi^{2}(5)=147.910 \\
(\mathrm{P}-\mathrm{value}=0.00)\end{array}$ & $\begin{array}{l}\chi^{2}(5)=152.373 \\
(\mathrm{P} \text {-value }=0.00)\end{array}$ & $\begin{array}{l}\chi^{2}(5)=150.592 \\
(\mathrm{P} \text {-value }=0.00)\end{array}$ \\
\hline Individual Fixed Effects & Country & Country & Country & Country \\
\hline Adjusted R-squared & 0.774 & 0.774 & 0.773 & 0.774 \\
\hline F-statistic & 38.803 & 37.427 & 37.428 & 37.491 \\
\hline Prob (F-statistic) & 0.000 & 0.000 & 0.000 & 0.000 \\
\hline Observation & 331 & 331 & 331 & 331 \\
\hline
\end{tabular}

Note: * represents $10 \%$ significant level. $* *$ represents $5 \%$ significant level. $* * * 1 \%$ represents significant level. () represents the value of standard error. 


\subsection{Foreign Exchange Market Oriented Outward Foreign Direct Investment}

Foreign exchange reserves can be used to deal with domestic economic turmoil. This will affect investors' confidence in performing foreign direct investments. If a country with a lot of foreign exchange reserves, this will bring a sense of security to investors. Then, investors will be willing to invest more to a country with large foreign exchange reserves. Stated differently, the foreign exchange reserve is positively related to the foreign direct investment. Before conducting empirical analyses, we perform Hausaman tests to decide which effect is proper between random effect and fixed effect. Referring to the relevant statistics of Hausaman tests, we find that the individual fixed effect is more suitable. The estimated results of foreign exchange market oriented outward foreign direct investment are shown in $<$ Table $5>$.

Table 5 presents the estimated results of foreign exchange market oriented outward foreign direct Investment. We will mainly focus on model (8). It can be found that both the coefficients of logexchange and $\mathrm{fta}_{e} \bullet \log$ exchange get through the significant test $5 \%$ level. This means that an increase in the foreign exchange reserve of a country who has not signed FTA with China will increase China's foreign direct investment amount to that country. When the foreign exchange reserve increases by $1 \%$, China's foreign direct investment amount to that country will be increased by $0.668 \%$. At the same time, an increase in the foreign exchange reserve of a country who has signed FTA with China will also increase China's foreign direct investment amount to that country. When the foreign exchange reserve increases by $1 \%$, China's foreign direct investment amount to that country will be increased by $0.789 \%(0.668 \%+0.121 \%=-0.789 \%)$. Therefore, we can summarize that in terms of foreign exchange market oriented outward foreign direct investment, a country who has signed FTA with China will receive more foreign direct Investment amount from China than that of a country who has not signed FTA with China.

Table 5: Results of Foreign Exchange Market Oriented Outward Foreign Direct Investment

\begin{tabular}{|c|c|c|c|c|}
\hline \multirow{2}{*}{$\begin{array}{c}\text { Dependent Variable } \\
\text { Model } \\
\text { Independent Variable } \\
\end{array}$} & \multicolumn{4}{|c|}{ ofdi } \\
\hline & $\begin{array}{c}\text { Model } \\
\text { (5) }\end{array}$ & $\begin{array}{l}\text { Model } \\
\text { (6) }\end{array}$ & $\begin{array}{c}\text { Model } \\
\text { (7) }\end{array}$ & $\begin{array}{c}\text { Model } \\
\text { (8) }\end{array}$ \\
\hline $\log g d p$ & $\begin{array}{c}1.566^{* * * *} \\
(0.575)\end{array}$ & $\begin{array}{l}1.557^{* *} \\
(0.685)\end{array}$ & $\begin{array}{l}1.571 * * \\
(0.780)\end{array}$ & $\begin{array}{l}1.570^{* *} \\
(0.676)\end{array}$ \\
\hline $\log g d p p c$ & $\begin{array}{l}1.567 * * \\
(0.785) \\
\end{array}$ & $\begin{array}{l}1.549^{*} \\
(0.818)\end{array}$ & $\begin{array}{l}1.497^{*} \\
(0.833)\end{array}$ & $\begin{array}{l}1.496^{* *} \\
(0.702)\end{array}$ \\
\hline $\log$ money & $\begin{array}{c}-0.351^{* *} \\
(0.128)\end{array}$ & $\begin{array}{l}-0.354 \\
(0.231)\end{array}$ & $\begin{array}{l}-0.350 \\
(0.229)\end{array}$ & $\begin{array}{l}-0.361^{*} \\
(0.230)\end{array}$ \\
\hline logexchange & $\begin{array}{l}0.704^{* *} \\
(0.326) \\
\end{array}$ & $\begin{array}{l}0.703^{*} \\
(0.367) \\
\end{array}$ & $\begin{array}{c}0.703 \\
(0.426) \\
\end{array}$ & $\begin{array}{l}0.668^{* *} \\
(0.339) \\
\end{array}$ \\
\hline$f t a_{e} \bullet \log g d p$ & & $\begin{array}{l}0.031^{* *} \\
(0.013)\end{array}$ & & \\
\hline$f t a_{e} \bullet \log g d p p c$ & & & $\begin{array}{l}-0.111 \\
(0.927)\end{array}$ & \\
\hline $\mathrm{fta}_{e} \bullet \log$ exchange & & & & $\begin{array}{c}0.121 * * \\
(0.056)\end{array}$ \\
\hline constant & $\begin{array}{c}-8.647 * * * \\
(2.169)\end{array}$ & $\begin{array}{c}-8.595^{* * *} \\
(2.255)\end{array}$ & $\begin{array}{c}-8.628^{* * *} \\
(2.178)\end{array}$ & $\begin{array}{c}-8.442 * * * \\
(2.214) \\
\end{array}$ \\
\hline Hausaman Test & $\begin{array}{l}\chi^{2}(4)=134.682 \\
(\mathrm{P}-\mathrm{value}=0.00)\end{array}$ & $\begin{array}{l}\chi^{2}(5)=147.910 \\
\text { (P-value }=0.00)\end{array}$ & $\begin{array}{l}\chi^{2}(5)=152.373 \\
(\mathrm{P} \text {-value }=0.00)\end{array}$ & $\begin{array}{l}\chi^{2}(5)=149.293 \\
\text { (P-value }=0.00)\end{array}$ \\
\hline Individual Fixed Effects & Country & Country & Country & Country \\
\hline Adjusted R-squared & 0.774 & 0.774 & 0.773 & 0.774 \\
\hline F-statistic & 38.803 & 37.427 & 37.428 & 37.461 \\
\hline Prob (F-statistic) & 0.000 & 0.000 & 0.000 & 0.000 \\
\hline Observation & 331 & 331 & 331 & 331 \\
\hline
\end{tabular}

Note: * represents $10 \%$ significant level. ** represents $5 \%$ significant level. $* * * 1 \%$ represents significant level. () represents the standard errors.

When taking model (4) in $<$ Table $4>$ and model (8) in $<$ Table 5> into consideration, it can be known the difference between a country who has signed FTA with China and a country who has not signed FTA in terms of money market and foreign exchange market. Stated specifically, a country who has signed FTA with China will receive more foreign direct investment amount from China than that of a country who has not signed FTA with China.

\subsection{Robustness Test}

Due to that independent variables such as the money 
supply, foreign exchange reserve, GDP and GDP per capita can be influenced by the outward foreign direct investment,

the estimated results in $<$ Table $4>$ and $<$ Table $5>$ may be biased.

Table 6: PGMM Estimated Result of Money Market Oriented Outward Foreign Direct Investment

\begin{tabular}{|c|c|c|c|c|}
\hline \multirow{2}{*}{\begin{tabular}{|c|} 
Dependent Variable \\
Model \\
Independent Variable
\end{tabular}} & \multicolumn{4}{|c|}{$\log o f d i$} \\
\hline & $\begin{array}{c}\text { Model } \\
\text { (9) }\end{array}$ & $\begin{array}{c}\text { Model } \\
\text { (10) }\end{array}$ & $\begin{array}{l}\text { Model } \\
\text { (11) }\end{array}$ & $\begin{array}{l}\text { Model } \\
\text { (12) }\end{array}$ \\
\hline $\log g d p$ & $\begin{array}{l}1.002 * * \\
(0.426)\end{array}$ & $\begin{array}{c}0.762 \\
(0.589)\end{array}$ & $\begin{array}{l}1.182 * * \\
(0.485)\end{array}$ & $\begin{array}{c}0.963 * * \\
(0.461)\end{array}$ \\
\hline $\log g d p p c$ & $\begin{array}{c}0.176 \\
(0.195)\end{array}$ & $\begin{array}{l}-0.536 \\
(0.196)\end{array}$ & $\begin{array}{l}0.343^{*} \\
(0.191)\end{array}$ & $\begin{array}{c}0.315^{* *} \\
(0.159)\end{array}$ \\
\hline $\log$ money & $\begin{array}{c}-0.706^{* *} \\
(0.289)\end{array}$ & $\begin{array}{c}-0.814 * * * \\
(0.268)\end{array}$ & $\begin{array}{l}-0.484^{*} \\
(0.274)\end{array}$ & $\begin{array}{l}-0.555^{*} \\
(0.354)\end{array}$ \\
\hline log exchange & $\begin{array}{c}0.612 * * \\
(0.266)\end{array}$ & $\begin{array}{c}0.704 * * * \\
(0.256)\end{array}$ & $\begin{array}{c}0.342 \\
(0.247)\end{array}$ & $\begin{array}{l}0.582 * \\
(0.299)\end{array}$ \\
\hline$f t a_{m} \bullet \log g d p$ & & $\begin{array}{c}1.336^{* * *} \\
(0.266)\end{array}$ & & \\
\hline$f t a_{m} \bullet \log g d p p c$ & & & $\begin{array}{c}-3.967 * * * \\
(0.295)\end{array}$ & \\
\hline$f t a_{m} \bullet \log$ money & & & & $\begin{array}{l}0.225^{*} \\
(0.145)\end{array}$ \\
\hline constant & $\begin{array}{c}1.890 \\
(5.959)\end{array}$ & $\begin{array}{c}4.197 \\
(8.361)\end{array}$ & $\begin{array}{c}2.481 \\
(6.137)\end{array}$ & $\begin{array}{c}1.320 \\
(7.584)\end{array}$ \\
\hline Adjusted R-squared & 0.762 & 0.745 & 0.755 & 0.762 \\
\hline Individual Fixed Effects & Country & Country & Country & Country \\
\hline J-statistic & 16.911 & 15.611 & 16.114 & 16.927 \\
\hline $\mathrm{P}$-value & 0.391 & 0.408 & 0.374 & 0.323 \\
\hline Observation & 171 & 171 & 171 & 171 \\
\hline Instrumental Variable & $g d$ & mone & $e_{t-n}, e x$ & $\tan t$ \\
\hline
\end{tabular}

Note: * represents $10 \%$ significant level. ** represents $5 \%$ significant level. ${ }^{* * *} 1 \%$ represents significant level. () represents the standard errors. $n$ is equal to $1,2,3$ and 4 .

Table 7: PGMM Estimated Result of Foreign Exchange Market Oriented Outward Foreign Direct Investment

\begin{tabular}{|c|c|c|c|c|}
\hline \multirow{2}{*}{$\begin{array}{c}\text { Dependent Variable } \\
\text { Model } \\
\text { Independent Variable } \\
\end{array}$} & \multicolumn{4}{|c|}{$\log o f d i$} \\
\hline & Model (13) & Model (14) & Model (15) & Model (16) \\
\hline $\log g d p$ & $\begin{array}{l}1.002 * * \\
(0.426)\end{array}$ & $\begin{array}{c}0.762 \\
(0.589)\end{array}$ & $\begin{array}{l}1.182 * * \\
(0.485)\end{array}$ & $\begin{array}{l}1.075 * * \\
(0.468)\end{array}$ \\
\hline $\log g d p p c$ & $\begin{array}{c}0.176 \\
(0.195)\end{array}$ & $\begin{array}{l}-0.536 \\
(0.196)\end{array}$ & $\begin{array}{l}0.343^{*} \\
(0.191)\end{array}$ & $\begin{array}{c}0.443^{* * *} \\
(0.126)\end{array}$ \\
\hline $\log$ money & $\begin{array}{c}-0.706^{* *} \\
(0.289) \\
\end{array}$ & $\begin{array}{c}-0.814 * * * \\
(0.268)\end{array}$ & $\begin{array}{l}-0.484^{*} \\
(0.274) \\
\end{array}$ & $\begin{array}{c}-0.806^{* * * *} \\
(0.296)\end{array}$ \\
\hline log exchange & $\begin{array}{l}0.612 * * \\
(0.266)\end{array}$ & $\begin{array}{c}0.704 * * * \\
(0.256)\end{array}$ & $\begin{array}{c}0.342 \\
(0.247)\end{array}$ & $\begin{array}{l}0.514^{*} \\
(0.273)\end{array}$ \\
\hline$f t a_{e} \bullet \log g d p$ & & $\begin{array}{c}1.336^{* * *} \\
(0.266)\end{array}$ & & \\
\hline$f t a_{e} \bullet \log g d p p c$ & & & $\begin{array}{c}-3.967 * * * \\
(0.295)\end{array}$ & \\
\hline$f t a_{e} \bullet \log$ exchange & & & & $\begin{array}{c}0.434 * * * \\
(0.135)\end{array}$ \\
\hline constant & $\begin{array}{c}1.890 \\
(5.959) \\
\end{array}$ & $\begin{array}{c}4.197 \\
(8.361) \\
\end{array}$ & $\begin{array}{c}2.481 \\
(6.137) \\
\end{array}$ & $\begin{array}{c}2.464 \\
(6.318) \\
\end{array}$ \\
\hline Adjusted R-squared & 0.762 & 0.745 & 0.755 & 0.754 \\
\hline Individual Fixed Effects & Country & Country & Country & Country \\
\hline J-statistic & 16.911 & 15.611 & 16.114 & 16.239 \\
\hline P-value & 0.391 & 0.408 & 0.374 & 0.366 \\
\hline Observation & 171 & 171 & 171 & 171 \\
\hline Instrumental Variable & & $\operatorname{lpp}_{t-n}$ & exchange $_{t}$ & \\
\hline
\end{tabular}

Note: * represents $10 \%$ significant level. $* *$ represents $5 \%$ significant level. $* * * 1 \%$ represents significant level. () represents the standard errors. $n$ is equal to $1,2,3$ and 4 . 
Therefore, we will fulfil the panel generalized method of moments (PGMM) estimation to take into consideration any endogeneity of independent variables. The estimated results of generalized method of moments are shown in $<$ Table $6>$ and $<$ Table $7>$.

Table 6 presents the PGMM estimated results of money market oriented outward foreign direct investment. It can be observed that the fundamental characteristics of $<$ Table $6>$ are basically the same as that of $<$ Table $4>$. Only the magnitude of the coefficients and their significance have changed a little. Moreover, in model (12), Hansen's (1982) $\mathrm{J}$-statistic is 16.927 with a p-value of 0.323 . This suggests that model (12) is well specified. That is to say, the estimated results in $<$ Table $4>$ are reliable and robust.

Table 7 presents the PGMM estimated results of foreign exchange market oriented outward foreign direct investment. It can be observed that the fundamental characteristics of $\langle$ Table $7>$ are basically the same as that of $\langle$ Table $5>$. Only the magnitude of the coefficients and their significance have changed a little. Moreover, in model (16), Hansen's (1982) J-statistic is 16.239 with a p-value of 0.366 . This suggests that model (16) is well specified. Said differently, the estimated results in $<$ Table $5>$ are reliable and robust.

\subsection{Effect of Global Economic Crisis on Outward Foreign Direct Investment}

In 2008, the global economic crisis swept through, almost any countries are spared the benefit to drop even deficit, of course including China. This paper mainly focuses on two aspects. One is the effect of global economic crisis on money market oriented outward foreign direct investment (from China to Asian countries). Another is the effect of global economic crisis on foreign exchange market oriented outward foreign direct investment (from China to Asian countries). Both of these two aspects will be analyzed, respectively. Before conducting empirical analyses, we perform Hausaman tests to decide which effect is proper between random effect and fixed effect. Referring to the relevant statistics of Hausaman tests, we find that the individual fixed effect is more suitable. The estimated results are shown in $<$ Table $8>$ and $<$ Table $9>$.

Table 8: Effect of Global Economic Crisis on Money Market Oriented Outward Foreign Direct Investment

\begin{tabular}{|c|c|c|c|c|}
\hline $\begin{array}{c}\text { Dependent } \\
\text { Variable }\end{array}$ & \multicolumn{4}{|c|}{$\log o f d i$} \\
\hline $\begin{array}{c}\text { Model } \\
\text { Independent Variable }\end{array}$ & $\begin{array}{c}\text { Model } \\
\text { (17) }\end{array}$ & $\begin{array}{c}\text { Model } \\
\text { (18) }\end{array}$ & $\begin{array}{c}\text { Model } \\
\text { (19) }\end{array}$ & $\begin{array}{l}\text { Model } \\
\text { (20) }\end{array}$ \\
\hline $\log g d p$ & $\begin{array}{c}1.566^{* * *} \\
(0.575)\end{array}$ & $\begin{array}{c}0.856 \\
(0.594)\end{array}$ & $\begin{array}{l}0.974 * \\
(0.596)\end{array}$ & $\begin{array}{l}1.161 * * \\
(0.579)\end{array}$ \\
\hline $\log g d p p c$ & $\begin{array}{l}1.567^{* *} \\
(0.785) \\
\end{array}$ & $\begin{array}{l}1.652^{* *} \\
(0.768) \\
\end{array}$ & $\begin{array}{l}1.921^{* * *} \\
(0.780)\end{array}$ & $\begin{array}{l}1.311^{*} \\
(0.796)\end{array}$ \\
\hline $\log$ money & $\begin{array}{l}-0.351 \\
(0.228) \\
\end{array}$ & $\begin{array}{l}-0.396^{*} \\
(0.220) \\
\end{array}$ & $\begin{array}{l}-0.293 \\
(0.223) \\
\end{array}$ & $\begin{array}{l}-0.373^{*} \\
(0.223)\end{array}$ \\
\hline log exchange & $\begin{array}{l}0.704^{* *} \\
(0.326) \\
\end{array}$ & $\begin{array}{l}0.600^{*} \\
(0.322) \\
\end{array}$ & $\begin{array}{l}0.576^{* *} \\
(0.225) \\
\end{array}$ & $\begin{array}{c}0.657^{* * *} \\
(0.222)\end{array}$ \\
\hline$d_{2008} \bullet \log g d p$ & & $\begin{array}{c}0.168 * * * \\
(0.041)\end{array}$ & & \\
\hline$d_{2008} \bullet \log g d p p c$ & & & $\begin{array}{c}0.095^{* * *} \\
(0.027)\end{array}$ & \\
\hline$d_{2008} \bullet \log$ money & & & & $\begin{array}{c}-0.087 * * * \\
(0.024)\end{array}$ \\
\hline constant & $\begin{array}{c}-8.647 * * * \\
(2.169)\end{array}$ & $\begin{array}{c}-7.764 * * * \\
(2.124)\end{array}$ & $\begin{array}{c}-8.639^{* * *} \\
(2.129)\end{array}$ & $\begin{array}{c}-6.738^{* * *} \\
(2.192) \\
\end{array}$ \\
\hline Hausaman Test & $\begin{array}{l}\chi^{2}(4)=134.682 \\
\text { (P-value }=0.00)\end{array}$ & $\begin{array}{l}\chi^{2}(5)=66.850 \\
(\mathrm{P} \text {-value }=0.00)\end{array}$ & $\begin{array}{l}\chi^{2}(5)=60.140 \\
(\text { P-value }=0.00)\end{array}$ & $\begin{array}{l}\chi^{2}(5)=64.102 \\
\text { (P-value }=0.00)\end{array}$ \\
\hline Individual Fixed Effects & Country & Country & Country & Country \\
\hline Adjusted R-squared & 0.774 & 0.786 & 0.783 & 0.783 \\
\hline F-statistic & 38.803 & 40.094 & 39.350 & 39.459 \\
\hline Prob (F-statistic) & 0.000 & 0.000 & 0.000 & 0.000 \\
\hline Observation & 331 & 331 & 331 & 331 \\
\hline
\end{tabular}

Note: * represents $10 \%$ significant level. $* *$ represents $5 \%$ significant level. $* * * 1 \%$ represents significant level. () represents the standard errors.

Table 8 presents the estimated results of global economic crisis on money market oriented outward foreign direct Investment. Model (20) will be focused on. Before 2008 , when the money supply increases by $1 \%$, the money market oriented outward foreign direct investment amount will be decreased by $0.373 \%$. Conversely, after 2008 , when the money supply increases by $1 \%$, the money market oriented outward foreign direct investment amount will 
also be decreased by $0.460 \%(0.373 \%+0.087 \%=0.360 \%)$. This means that the global economic crisis happened in 2008 will reduce the money market oriented outward foreign direct investment amount from China to Asian countries.

Table 9: Results of Global Economic Crisis on Foreign Exchange Market Oriented Outward Foreign Direct Investment

\begin{tabular}{|c|c|c|c|c|}
\hline \multirow{2}{*}{$\begin{array}{c}\text { Dependent Variable } \\
\text { Model } \\
\text { Independent Variable } \\
\end{array}$} & \multicolumn{4}{|c|}{$\log o f d i$} \\
\hline & Model & Model & Model & Model \\
\hline$\frac{\text { Independent Variable }}{\log g d p}$ & $\begin{array}{c}1.566^{* * * *} \\
(0.575)\end{array}$ & $\begin{array}{c}(2 .) \\
0.856 \\
(0.594)\end{array}$ & $\begin{array}{l}0.974 * \\
(0.596)\end{array}$ & $\begin{array}{l}1.017^{* *} \\
(0.482)\end{array}$ \\
\hline $\log g d p p c$ & $\begin{array}{l}1.567^{* *} \\
(0.785)\end{array}$ & $\begin{array}{l}1.652^{* *} \\
(0.768)\end{array}$ & $\begin{array}{l}1.921^{* *} \\
(0.780)\end{array}$ & $\begin{array}{l}1.512 * * \\
(0.668)\end{array}$ \\
\hline $\log$ money & $\begin{array}{l}-0.351 \\
(0.228) \\
\end{array}$ & $\begin{array}{c}-0.396^{*} \\
(0.220)\end{array}$ & $\begin{array}{l}-0.293 \\
(0.223) \\
\end{array}$ & $\begin{array}{c}-0.500 * * * \\
(0.122)\end{array}$ \\
\hline logexchange & $\begin{array}{l}0.704 * * \\
(0.326)\end{array}$ & $\begin{array}{l}0.600^{*} \\
(0.322)\end{array}$ & $\begin{array}{l}0.576^{* *} \\
(0.225)\end{array}$ & $\begin{array}{l}0.485^{* *} \\
(0.227)\end{array}$ \\
\hline$d_{2008} \bullet \log g d p$ & & $\begin{array}{c}0.168^{* * *} \\
(0.041)\end{array}$ & & \\
\hline$d_{2008} \bullet \log g d p p c$ & & & $\begin{array}{l}0.095 * * * \\
(0.027)\end{array}$ & \\
\hline$d_{2008} \bullet \log$ exchange & & & & $\begin{array}{c}-0.199 * * * \\
(0.048)\end{array}$ \\
\hline constant & $\begin{array}{c}-8.647 * * * \\
(2.169) \\
\end{array}$ & $\begin{array}{c}-7.764 * * * \\
(2.124) \\
\end{array}$ & $\begin{array}{c}-8.639 * * * \\
(2.129) \\
\end{array}$ & $\begin{array}{c}-7.709 * * * \\
(2.126) \\
\end{array}$ \\
\hline Hausaman Test & $\begin{array}{l}\chi^{2}(4)=134.682 \\
(\mathrm{P}-\mathrm{value}=0.00)\end{array}$ & $\begin{array}{l}\chi^{2}(5)=66.850 \\
(\mathrm{P}-\text { value }=0.00)\end{array}$ & $\begin{array}{l}\chi^{2}(5)=60.140 \\
(\mathrm{P}-\text { value }=0.00)\end{array}$ & $\begin{array}{l}\chi^{2}(5)=86.200 \\
(\mathrm{P}-\text { value }=0.00)\end{array}$ \\
\hline Individual Fixed Effects & Country & Country & Country & Country \\
\hline Adjusted R-squared & 0.774 & 0.786 & 0.783 & 0.786 \\
\hline F-statistic & 38.803 & 40.094 & 39.350 & 40.076 \\
\hline Prob (F-statistic) & 0.000 & 0.000 & 0.000 & 0.000 \\
\hline Observation & 331 & 331 & 331 & 331 \\
\hline
\end{tabular}

Note: * represents $10 \%$ significant level. ** represents $5 \%$ significant level. ***1\% represents significant level. () represents the standard errors.

Table 9 presents the estimated results of effect of global economic crisis on foreign exchange market oriented outward foreign direct Investment. An attention will be payed to model (24). Before 2008, when the foreign exchange reserve increases by $1 \%$, the foreign exchange market oriented outward foreign direct investment amount will be increased by $0.485 \%$. On the contrary, after 2008 , when the foreign exchange reserve increases by $1 \%$, the foreign exchange market oriented outward foreign direct investment amount will also be increased by $0.286 \%$ $(0.485 \%-0.199 \%=0.286 \%)$. This means that the global economic crisis happened in 2008 will reduce the foreign exchange market oriented outward foreign direct investment amount from China to Asian countries.

\section{Conclusions and Limitations}

Economic globalization accelerates the integration of countries and provides channels for outward foreign direct investment. Due to the increase of uncertainties, the outward foreign direct investment patterns of all countries in the world have been in dynamic fluctuations. Therefore, this paper regards China as an example to analyze China's outward foreign direct investment patterns in terms of Asian financial markets (money market and foreign exchange market) with a panel data over the period from 2003 to 2017. We mainly focus on the money market oriented outward foreign direct investment and the foreign exchange market oriented outward foreign direct investment. Because some Asian countries have signed the Free Trade Agreement (FTA) with China, this behavior will affect China's outward foreign direct investment patterns to these Asian countries. For this reason, dummy variables (If a country has signed FTA with China, the value will be one. Otherwise, zero.) are set to guarantee the accuracy of the estimated results. Using the individual fixed effect model to conduct empirical analyses, the empirical findings indicate that China will reduce its foreign direct investment amount to a country with large money supply and China will increase its foreign direct investment amount to a country with large foreign exchange reserves. Furthermore, when a country has signed FTA with China, China will increase more foreign direct investment amount to these countries than that of a country who has not signed FTA with China. Besides, due to that independent variables such as the money supply, foreign exchange reserve, GDP and GDP per capita can be 
influenced by the outward foreign direct investment, the estimated results in this paper may be biased. Therefore, we will fulfil the panel generalized method of moments estimation to take into consideration any endogeneity of independent variables. The estimated results of the panel generalized method of moments bear out that the empirical findings in this paper are reliable and robust. Additionally, we also take the global economic crisis happened in 2008 into account. A dummy variable (Before 2008, the value will be zero. Otherwise, the value will be one.) is set to explore the effect of global economic crisis on China's outward foreign direct investment patterns to Asian countries. We also employ the individual fixed effect model to conduct empirical analyses. the empirical findings indicate that no matter what the money market oriented outward foreign direct investment or the foreign market oriented outward foreign direct investment, China will reduce its foreign direct investment amount to these Asian countries due to the global economic crisis.

Of course, these are some limitations in this paper. Firstly, there are 48 countries in Asia except China. However, due to some countries' data missing, we can only collect 27 countries to conduct empirical analyses. This may not fully reflect the effect of Asian financial markets on China's outward foreign direct investment patterns. Secondly, the time span of this paper is only 15 years. Relatively speaking, it is still relatively short, which may affect the accuracy of the estimation results in this paper. Finally, according to the general international standards, financial markets can be divided into money market, capital market, foreign exchange market and gold market. This paper only chooses the money market and the foreign exchange market to discuss the effect of financial market on China's outward foreign direct investment patterns. This behavior may not fully reflect the function of financial market to China's outward foreign direct investment patterns. Meanwhile, these limitations also leave room for scholars who have similar interests to continue to explore the proposition.

\section{References}

Bhasin, N., \& Jain, V. (2015). Outward FDI from India: An examination into the role of host country factors. Transnational Corporations Review, 7(3), 316-334. doi.org/10.5148/tncr.2015.7305

Blomkvist, K., \& Drogendijk, R. (2013). The impact of psychic distance on Chinese outward foreign direct investments. Management International Review, 53(5), 659-686. doi: 10.1007/s11575-012-0147-y

Chen, J. E., \& Zulkifli, S. A. M. (2012). Malaysian outward FDI and economic growth. Procedia-Social and
Behavioral Sciences, 65, 717-722.

doi.org/10.1016/j.sbspro.2012.11.189

Chou, K. H., Chen, C. H., \& Mai, C. C. (2011). The impact of third-country effects and economic integration on China's outward FDI. Economic Modelling, 28(5), 2154-2163. doi.org/10.1016/j.econmod.2011.05.012

Clegg, J., Lin, H. M., Voss, H., Yen, I. F., \& Shih, Y. T. (2016). The OFDI patterns and firm performance of Chinese firms: The moderating effects of multinationality strategy and external factors. International Business Review, 25(4), 971-985. doi.org/10.1016/j.ibusrev.2016.01.010

Hansen, L. P. (1982). Large sample properties of generalized method of moments estimators. Econometrica: Journal of the Econometric Society, 50(4) 1029-1054. doi: 10.2307/1912775

He, Y. (2018). A Study on the Impact of Real Exchange Rate Volatility of RMB on China's Foreign Direct Investment to Japan. East Asian Journal of Business Economics, 6(3), 24-36.

doi: org/10.20498/eajbe.2018.6.24

Kang, M.-J., \& Kim, S. H. (2014). The Entry Modes Strategy in FDI: Expansion of Korean Retailers into China and Indonesia. Journal of Distribution Science, 12(7), 45-51. doi: 10.13106/jds.2014.vol12.no7.45

Lee, S. J., \& Zhai, S. (2013). An Empirical Study on the Export and Import Effects of Foreign Direct Investment on the Blue Economic Zone of the Shandong Peninsula in China. Journal of Distribution Science, 11(1), 15-23. doi: $10.15722 /$ jds.11.1.201301.15

Lee, C. G. (2010). Outward foreign direct investment and economic growth: Evidence from Japan. Global Economic Review, 39(3), 317-326. doi: 10.1080/1226508X.2010.513143

Li, Z., Huang, Z., \& Dong, H. (2019). The Influential Factors on Outward Foreign Direct Investment: Evidence from the "The Belt and Road". Emerging Markets Finance and Trade, 53(6), 1-16. doi.org/10.1080/1540496X.2019.1569512

Liu, Y., Ge, Y., Hu, Z., \& Wang, S. (2018). Culture and capital flows-Exploring the spatial differentiation of China's OFDI. China Economic Review, 48, 27-45. https://doi.org/10.1016/j.chieco.2017.10.007

Patel, D., \& Mah, G. (2018). Relationship between real exchange rate and economic growth: the case of South Africa. Journal of Economics and Behavioral Studies, 10(1), 146-158. doi: 10.22610/jebs. v10i1. 2098.g1590

Yan, B., Zhang, Y., Shen, Y., \& Han, J. (2018). Productivity, financial constraints and outward foreign direct investment: Firm-level evidence. China Economic Review, 47, 47-64.

https://doi.org/10.1016/j.chieco.2017.12.006

Yoo, J. G. (2016). An economic effect analysis of ASEAN 
FTA on FDI flows into the ASEAN countries. Journal of Distribution Science, 14(1), 39-49.

doi: $10.15722 /$ jds.14.1.201601.39

Wang, Y., Cheng, L., Wang, H., \& Li, L. (2014). Institutional quality, financial development and OFDI. Pacific Science Review, 16(2), 127-132. doi.org/10.1016/j.pscr.2014.08.023

Wei, W., Alon, I., \& Ni, L. (2012). Home country macroeconomic determinants of Chinese OFDI. In
Chinese International Investments (pp. 38-53). Palgrave Macmillan, London. DOI: 10.1057/9780230361577_3

Wei, Y., Zheng, N., Liu, X., \& Lu, J. (2014). Expanding to outward foreign direct investment or not? A multidimensional analysis of entry mode transformation of Chinese private exporting firms. International Business Review, 23(2), 356-370.

doi.org/10.1016/j.ibusrev.2013.06.001 